IFN Working Paper No. 1012, 2014

\title{
Sizing Up the Impact of Embassies on Exports
}

\author{
Shon Ferguson and Rikard Forslid
}




\title{
Sizing Up the Impact of Embassies on Exports*
}

\author{
Shon Ferguson ${ }^{\dagger}$ and Rikard Forslid ${ }^{\ddagger}$
}

February 2014

\begin{abstract}
The purpose of this study is to test for the effects of trade promotion via the foreign service. We develop a Melitz-based model where firms are heterogeneous with respect to productivity and must pay a beachhead cost to enter a foreign market, which can be reduced by government spending on trade promotion. The model predicts that unilateral trade promotion allows medium-sized firms to export. We test this prediction using Swedish firmlevel data and information on the opening and closing of Swedish embassies abroad using Norwegian firms as control group. Our results lend support to the predictions of the model, with large and medium-sized firms responding most strongly to the opening of embassies.
\end{abstract}

JEL Classification: D21, D22, F12, F15

Keywords: heterogeneous firms, trade promotion

\section{Introduction}

Virtually all countries have foreign representation e.g. in the form of embassies and consulates. However, as information costs fall in the era of the internet, the raison d'être of foreign representations is in question, as pointed out by Rose (2007). The response of the foreign services in many countries is that their activities are important for promoting trade. This would be particularly true for Sweden, which is a small open economy that has not been involved in military conflicts for 200 years. ${ }^{1}$ Given the large sums spent on maintaining embassies abroad and the popular aim of governments to promote the exports of "Small- and Medium-Sized Enterprises" (SMEs) it is surprising how little we know about how trade promotion via the foreign service affects different types of firms.

\footnotetext{
${ }^{*}$ The authors thank Peter Fredriksson and seminar participants at ETSG 2013 and Lund University for comments and suggestions. Financial support from the Swedish Research Council, the Wallander Hedelius Foundation and the Marianne and Marcus Wallenberg Foundation is gratefully acknowledged. We especially thank Esther Ann Bøler för assistance with the Norwegian data. This paper was earlier circulated under the name "The heterogeneous effects of trade facilitation: theory and evidence".

${ }^{\dagger}$ Research Institute of Industrial Economics (IFN), email: shon.ferguson@ifn.se.

${ }^{\ddagger}$ Stockholm University, CEPR; email: rf@ne.su.se.

${ }^{1}$ Sweden has however contributed troops to UN-missions.
} 
This paper uses Swedish firm level data from 1997-2007 to measure the effect of Swedish embassies on Swedish exports. We start out from a theoretical framework of heterogenous firms following Melitz (2003), where the role of embassies is to diminish firms' fixed entry cost to the country where an embassy is located. One central result from the model is that export promotion allows smaller firms to export. However, the largest firms that already export and the very small firms that never export are not affected by lower entry costs. The theoretical results from this exercise is taken to data.

We test for the effect of trade promotion on the extensive margin by combining firm-level data on the exports by destination of Swedish firms with information on the location of Swedish embassies abroad. We find that a larger number of medium-sized and large firms begin exporting to countries after Sweden opens an embassy, and that the number drops when Sweden closes an embassy. This evidence lends support to our theoretical model. We first perform the analysis at the industry-level and find that embassies are associated with a $5 \%$ increase in the number of exporters. We then perform the analysis dividing exporters into quartiles dependent on the number of employees relative to other firms in their industry. Using this more disaggregated data we find that the effect of an embassy is strongest in the third and fourth quartiles of the firm size distribution. The point estimates suggest that embassies are associated with a $12 \%$ and $5 \%$ increase in the number of exporters from the third and fourth quartiles respectively.

In order to establish that our results are consistent with the hypothesis that export promotion via the foreign service reduce entry barriers we examine the extensive margin of exporting before, during, and after the embassies were built. We detect a distinct increase in medium-sized exporters after an embassy is built.

In order to get a stronger identification, we use data on Norwegian exports as a control group. Norwegian and Swedish firms are from a global perspective highly similar in many respects, including location. In a placebo regression we find that the number of Norwegian exporters did not respond to the opening and closing of Swedish embassies, which suggests that the results are not driven spuriously by other factors that affect both economic and diplomatic openness. We also use a difference-in-difference approach with Swedish firms in the treatment group and Norwegian firms in the control group. ${ }^{2}$ Our results are robust to a several robustness checks such as restricting the sample to industries with low levels of firm concentration and to include only countries where Swedish embassies were opened.

While many studies have studied the impact of trade promotion in its many forms on aggregate trade and various extensive and intensive margins of trade, the heterogenous response in terms of firm size has received less attention. ${ }^{3}$ Using aggregate cross-country data, Rose (2007) finds a positive and significant effect of a country's foreign service on it's export, Lederman, Olarreaga, and Payton (2010) find that national export promotion agencies have a positive

\footnotetext{
${ }^{2}$ An exception is of course the Norwegian oil industry, which is left outside our analysis.

${ }^{3}$ Our paper is also related to the large literature on the effects of unilateral trade reforms at the firm level (see e.g. Trefler (2004), and Breinlich and Cuñat (2010))
} 
impact on exports, and Nitsch (2007) finds that state visits promote trade. These results on aggregate trade flows do not inform us of whether export promotion promote export by increasing the exports of existing exporters (intensive margin) or if they make it easier for new firms to enter the market (extensive margin), and recent work has therefore turned to firm level data. ${ }^{4}$

Recent work has also studied how firm characteristics affect the response of the intensive margin to export subsidies and grants. Girma, Gong, Görg, and Yu (2009) find that the intensive margin of exports is more responsive to export subsidies for profit-making firms, firms in capital-intensive industries, and firms in non-coastal regions. Görg, Henry, and Strobl (2008) find the intensive margin of exports response more to export grants in larger firms, measured as the number of employees.

The studies most related to our work are the empirical studies by Volpe Martincus and Carballo $(2008,2010)$, who analyse the effect of export promotion by Peru's national export promotion agency PROMPEX. Their identification strategy is to match firms on observables and then to perform a difference in difference in difference estimation comparing treated firms before and after treatment to matched non-treated firms in the same time intervals. Volpe Martincus and Carballo (2008) find that export promotion has a postive effect on the extensive margin, but no significant effect on the intensive margin. With the same data Volpe Martincus and Carballo (2010) uses a similar approach but now also divides firms into quantiles according to export growth. Here they find significant positive effects on the export volume for firms in the lower quantiles, while the number of export countries increase in the lower and upper quantiles. A difficulty is that firm export growth not directly translates into firm size. Estimating kernel densities of firm export levels the previous year shows that export promotion on average is more efficient for small firms. Finally, Volpe Martincus, Carballo, and Garcia (2012) evaluate the effect of Argentinas' export promotion programme over the period 2002 to 2006 . They find that the effects are larger for smaller firms. A limitation of the study is that the data for firms' export is aggregated over destinations.

Our paper instead focuses on the foreign service and uses a difference-in-difference strategy using Norwegian export data as the control group. We divide firms into quartiles based on size. Our estimates show positive significant effects on the extensive margin (new firms starting to export) for firms in the fourth quartile of the firm size distribution.

The paper is organized as follows: Section 2 contains the theoretical model. The data are presented in Section 3, and the empirical specification and resuults are presented in Section 4. Finally, Section 5 concludes the paper.

\footnotetext{
${ }^{4}$ Some papers have used sector level data, and e.g. Persson (2013) finds that trade facilitation leads to a lager number of exported products at the 8-digit (Combined Nomenclature) sector level.
} 


\section{The Model}

\subsection{Basics}

This paper employs a modified version of the Melitz (2003) monopolistic competition trade model with heterogeneous firms. There are $m$ countries. Each country $j$ has a single primary factor of production labour, $L_{j}$, used in the A-sector and the M-sector. The A-sector is a Walrasian, homogenous-goods sector with costless trade. The M-sector (manufactures) is characterized by increasing returns, Dixit-Stiglitz monopolistic competition and iceberg trade costs. M-sector firms face constant marginal production costs and three types of fixed costs. The first fixed cost, $F_{E}$, is the standard Dixit-Stiglitz cost of developing a new variety. The second $F_{D}$ is an entry costs reflecting the one-time expense of introducing a new variety into the domestic market. There is also a 'beachhead' cost for the foreign market, but this cost can be lowered by trade promotion from the government. The entry cost in the foreign market is therefore $F_{X} / d_{j k}$, where $d_{j k}$ represents the effect of trade promotion by country $j$ in country $k$. Trade promotion is financed by an income tax. We assume that the beachhead costs $\left(F_{X}\right)$ are symmetric in order to simplify notation but countries' spending on trade promotion is allowed to be asymmetric. ${ }^{5}$

There is heterogeneity with respect to firms' marginal costs. Each Dixit-Stiglitz firm/variety is associated with a particular labour input coefficient - denoted as $a_{i}$ for firm $i$. After sinking $F_{E}$ units of labour in the product innovation process, the firm is randomly assigned an ' $a_{i}$ ' from a probability distribution $G(a)$.

Our analysis exclusively focuses on steady-state equilibria and intertemporal discounting is ignored; the present value of firms is kept finite by assuming that firms face a constant Poisson hazard rate $\delta$ of "death".

Consumers in each nation have a quasi-linear utility function over goods from the two sectors, while consumer's preferences over the various differentiated varieties within the Msector are dictated by a CES-index. This implies that expenditures on differentiated goods are constant and therefore independent of taxes (as long as endowments are such that both goods are produced in both countries). We therefore leave taxes outside the following analysis.

All individuals in country $j$ have the utility function

$$
U_{j}=C_{A j}+\mu \ln C_{M j}
$$

where $\mu \in(0,1)$ measures demand for manufactured goods, and $C_{A j}$ is consumption of the homogenous good. Manufactures enter the utility function through the index $C_{M j}$, defined by

$$
C_{M j}=\left[\int_{0}^{N_{j}} c_{i j}^{(\sigma-1) / \sigma} d i\right]^{\sigma /(\sigma-1)}
$$

$N_{j}$ being the mass of varieties consumed in country $j, c_{i j}$ the amount of variety $i$ consumed in country $j$, and $\sigma>1$ the elasticity of substitution.

\footnotetext{
${ }^{5}$ Our approach to modelling asymmetric fixed export costs is similar to Akerman and Forslid (2007).
} 
Each consumer spends $\mu$ of his income on manufactures, and demand for a variety $i$ in country $j$ is therefore

$$
x_{i j}=\frac{p_{i j}^{-\sigma}}{P_{j}^{1-\sigma}} \mu
$$

where $p_{i j}$ is the consumer price of variety $i$ in country $j$, and $P_{j} \equiv\left(\int_{0}^{N_{j}} p_{i j}^{1-\sigma} d i\right)^{\frac{1}{1-\sigma}}$ the price index of manufacturing goods in country $j$.

The unit factor requirement of the homogeneous good is one unit of labour. This good is freely traded and since it is chosen as the numeraire

$$
p_{A}=w=1
$$

$w$ being the nominal wage of workers in all countries.

Shipping the manufactured good involves a frictional trade cost of the "iceberg" form: for one unit of a good from country $j$ to arrive in country $k, \tau>1$ units must be shipped. It is assumed that trade costs are equal in both directions and that $\tau_{j j}=1$. Profit maximization by a manufacturing firm $i$ located in country $j$ leads to consumer price

$$
p_{i j k}=\frac{\sigma}{\sigma-1} \tau_{j k} a_{i}
$$

in country $k$.

Manufacturing firms draw their marginal cost, $a$, from the probability distribution $G(a)$ after having sunk $F_{E}$ units of labour to develop a new variety. Having learned their productivity, firms decide on entry in the domestic and foreign market, respectively. Firms will enter a market as long as the operating profit in this market is sufficiently large to cover the market entry cost associated with the market. Because of the constant mark-up pricing, it is easily shown that operating profits equal sales divided by $\sigma$. Using this and (3), the critical 'cut-off' levels of the marginal costs are given by:

$$
\begin{gathered}
a_{D j}^{1-\sigma} B_{j}=F_{D}, \\
a_{X j k}^{1-\sigma} \phi B_{k}=F_{X} / d_{j k},
\end{gathered}
$$

where $B_{j} \equiv \eta \mu / P_{j}^{1-\sigma}, \eta \equiv \frac{(\sigma-1)^{\sigma-1}}{\sigma^{\sigma}}$, and where $\phi \equiv \tau^{1-\sigma} \in[0,1]$ represents trade freeness. Trade promotion enters the model through $d_{j k}$, where $d_{j k}>1$ implies that trade promotion by country $j$ is reducing the fixed cost of export for its firms in country $k . d_{j k}$ is financed through income taxation $t$, but these taxes do not affect the demand for manufacturing goods because of the quasi-linear preferences. Firms will take the entry cost $F_{X} / d_{j k}$ as given when deciding which markets to enter.

Finally, free entry ensures that the ex-ante expected profit of developing a new variety in country $j$ equals the investment cost: 


$$
\int_{0}^{a_{D j}}\left(a^{1-\sigma} B_{j}-F_{D}\right) d G(a)+\sum_{k, k \neq j} \int_{0}^{a_{X j k}}\left(\phi a^{1-\sigma} B_{k}-F_{X} / d_{j k}\right) d G(a)=F_{E} .
$$

\subsection{Solving for the Long-run Equilibrium}

In this section, we apply two simplifying assumptions. First, the model is solved with two countries, $j$ and $k$. We refer to $j$ as "Home" and $k$ as "Foreign". Second, we follow Helpman, Melitz, and Yeaple (2004) in assuming the probability density function to be Pareto:

$$
G(a)=\left(\frac{a}{a_{0}}\right)^{\theta}
$$

We normalise the scale parameter so that $a_{0} \equiv 1$. Integrating (8) and using (6) and (7) gives $B_{j k}$,

$$
B_{j}=\left(\frac{F_{E} F_{D j}^{\beta-1} \eta^{1-\beta} \cdot(\beta-1)\left(1-d_{j k}^{\beta-1} \Omega\right)}{1-d_{j k}^{\beta-1} d_{k j}^{\beta-1} \Omega^{2}}\right)^{\frac{1}{\beta}}
$$

where $\beta \equiv \theta /(\sigma-1)>1$, and $\Omega \equiv \phi^{\beta}\left(F_{X} / F_{D}\right)^{1-\beta} \in[0,1]$ is an index of trade freeness. Using this expression, (6) and (7) gives the cut-off marginal costs. The cut-off for a domestic non-exporters is given by:

$$
a_{D j}^{\theta}=\frac{\eta(\beta-1) F_{E}\left(1-d_{j k}^{\beta-1} \Omega\right)}{F_{D}\left(1-d_{j k}^{\beta-1} d_{k j}^{\beta-1} \Omega^{2}\right)}
$$

where $d_{j k}^{\beta-1} \Omega \in[0,1] \forall j, k$ ensures a positive solution for the cutoff. The cut-off cost for exporters is given by

$$
a_{X j}^{\theta}=\frac{F_{E} \eta(\beta-1) \Omega d_{j k}^{\beta}\left(1-d_{k j}^{\beta-1} \Omega\right)}{F_{X}\left(1-d_{j k}^{\beta-1} d_{k j}^{\beta-1} \Omega^{2}\right)} .
$$

Proposition 1 (Home Country Effects): Unilateral home country export promotion will increase the marginal cost cut-off for exporters at Home, and decrease the marginal cost cut-off for non-exporters at Home if $\Omega<1$.

Proof: Home export promotion's positive effect on the marginal cost cut-offs for Home exporters follows from (12). See appendix A.1 for a proof that unilateral export promotion decreases the marginal-cost cut-offs for Home non-exporters if $\Omega<1$.

This model with asymmetric trade promotion leads to the prediction that unilateral trade promotion at Home leads to a softer cutoff for Home exporters due to the lower export beachhead cost. This means that trade promotion at home leads to lower average productivity among those firms exporting to the particular destination. However, the marginal cost cut-off becomes tougher at Home for non-exporters. This is a general equilibrium effect due to entry of new firms 
in Home. Lower export costs increase expected profits for Home firms, which leads to increased entry. The entry effect of trade promotion can clearly be seen in the equation describing the mass of firms in each country, which is derived below.

Proposition 2 (Foreign Country Effects): Unilateral home country export promotion will increase the marginal cost cut-off for non-exporting firms at Foreign and decrease the marginal cost cut-off for exporters at Foreign if $\Omega<1$.

Proof: Home trade promotion's positive effect on the marginal cost cut-offs for Foreign non-exporters follows from (11). See appendix A.2 for a proof that unilateral export promotion decreases the marginal-cost cut-offs for Foreign exporters if $\Omega<1$.

There are two forces that affect firms at Foreign. The presence of a greater number of Home exporters in the Foreign market toughens competition, while the lower expected profits of operating in Foreign lead to fewer firms at Foreign. The Home competition effect dominates for Foreign exporters, while the reduced entry leads to a softer cutoff for Foreign non-exporters.

We will assume that, in spite of trade promotion, it will never be easier to export than to sell in the domestic market, which implies that $a_{X j}<a_{D j} \forall j, k$. The condition for this to hold is $F_{X} / \Omega F_{D}>\left(d_{j k}^{\beta}\left(1-d_{k j}^{\beta-1} \Omega_{k j}\right)\right) /\left(1-d_{j k}^{\beta-1} \Omega_{j k}\right)$ for all $j, k$. The model reduces to the standard Melitz model if there is no trade promotion $\left(d_{j k}=d_{k j}=1\right)$.

To calculate the number (mass) of firms in each country, we first note that the price index in country $j$ may be written as

$$
P_{j}^{1-\sigma}=\Psi \frac{\beta}{\beta-1}\left(n_{j} a_{D j}^{1-\sigma}+n_{k} \phi a_{D k}^{1-\sigma}\left(\frac{a_{X k}}{a_{D k}}\right)^{\theta+1-\sigma}\right),
$$

where $\Psi=\left(\frac{\sigma}{\sigma-1}\right)^{1-\sigma}$. The mass of firms in each country can now be calculated using (6), (11), (12), and (13):

$$
n_{j}=\frac{\mu \eta(\beta-1)}{F_{D} \beta} \frac{\left(1-d_{k j}^{\beta-1} \Omega\right)-\left(1-d_{j k}^{\beta-1} \Omega\right) d_{k j}^{\beta-1} \Omega}{\left(1-d_{k j}^{\beta-1} \Omega\right)\left(1-d_{j k}^{\beta-1} d_{k j}^{\beta-1} \Omega^{2}\right)} .
$$

This equation shows how an increase in country $j^{\prime} s$ level of trade promotion, $d_{j k}$, will make it a more attractive location (base) for exporting firms. Trade promotion will affect the ex ante attractiveness of entry in country $j$, and it will therefore lead to a higher mass of firms in equilibrium. This also implies that the number (mass) of exporters increases in the level of export promotion.

Proposition 3 The number (mass) of Home exporters increases in the Home level of export promotion.

Proof: Proposition 1 implies that a larger share of the firms in Home export because of export promotion, and since $\frac{\partial n_{j}}{\partial d_{j k}}>0$ by inspection of (14) the proposition follows.

We turn now to an empirical test of these results. 


\section{Data}

We use annual manufacturing census data at the firm level from Statistics Sweden combined with data on opening and closing dates of Swedish embassies abroad between 1997 and 2007. The firm level data contains detailed information about firm exports by destination and firm, as well as the number of employees per firm, which we use as our measure of firm size. Export data from 143 4-digit NACE revision 1.1 industries are included in the analysis.

We measure export promotion using data on the presense or absence of Swedish embassies in several countries during the period 1997-2007. Of the 173 countries in the data for which we have data on the presence of an embassy, new embassies were opened and/or closed in 15 countries over this period. A list of Swedish embassy openings and closings between 1997 and 2007 is provided in Table 1. The countries in our sample tend to be smaller and/or distant markets in Europe, Africa and the Middle-East. We construct a dummy variable to capture the presence of an embassy, which takes a value of one in the years where an embassy is present in a country and zero otherwise. We do not include consulates in the analysis since these often serve a very limited purpose and are operated by locals.

Swedish firms are not obligated to report within-EU export statistics if their total exports to all EU countries are below a certain annual threshold. This annual threshold was SEK 0.9 million in 1997, SEK 1.5 million 1998-2004, and SEK 4.5 million in 2007. We correct for this change in the reporting thresholds by removing any firm-level export observations for firms with total exports to the EU15 that do not exceed SEK4.5million.

Our dependent variable is the logged number of exporters by firm size quartile, destination and 4-digit NACE rev.1.1 sector. Starting with the firm-level data, we thus assign each firm to a size quartile each year they are present in the data, then sum the number of exporters within each quartile by destination and sector. The size quartiles are calculated based on the entire sample for firms with 10 employees or more, which includes both exporters and non-exporters.

We include a number of control variables in the analysis such as population and GDP per capita (taken from CEPII data), which controls for destination country market potential. We also control for official development assistance transfers to each country as well as an EU membership dummy variable. We use average manufacturing tariffs ${ }^{6}$ (taken from the World Development Indicators) to proxy for changes in trade costs. Descriptive statistics for these variables are provided in Table 2. The export destinations in our sample differ widely in terms of population size and GDP per capita. More detailed export statistics by destination country are given in Table 3. There is a wide degree of export heterogeneity across 4-digit NACE industries, with the number of firms exporting in a given year and destination ranging from zero to 31 firms. The value of exports also varies across sectors, but Table 3 highlights the fact that exports to all of these destinations are non-negligible.

In the regression analysis we use Norwegian firm level data for our control group. This data

\footnotetext{
6 "Tariff rate, applied, simple mean, manufactured products"
} 
Table 1: Embassy openings and closures

\begin{tabular}{lcc} 
Country & year opened & year closed \\
\hline Congo, Dem. Rep. & 1998 & \\
Lebanon & 1998 & 2001 \\
Slovenia & 1999 & \\
Uganda & 1999 & \\
Senegal & 2000 & \\
Guinea-Bissau & & 2000 \\
Venezuela & & 2000 \\
United Arab Emirates & 2001 & \\
Kuwait & & 2001 \\
Peru & & 2001 \\
Tunisia & & 2001 \\
Cyprus & 2003 & \\
Slovakia & 2003 & \\
Macedonia & 2005 & \\
lvory Coast & & 2007 \\
& & \\
\hline
\end{tabular}

Source: Swedish Ministry of Foreign Affairs

Table 2: Industry and Destination Statistics, 2005

\begin{tabular}{lccc}
\hline & Mean & Min & Max \\
\hline Number of firms in industry & & & \\
population (millions) & 67 & 4 & 610 \\
GDP per capita (USD) & 7.7 & 0.8 & 28.2 \\
tariff (weighted, percent) & 22237 & 602 & 47249 \\
Official Development Assistance (MSEK) & 5.2 & 1.6 & 13.8 \\
& 2.1 & 0.0 & 51.6 \\
\hline
\end{tabular}

Note: Based on observations included in regression in Table 6, column (2). Source: Statistics Sweden, CEPII, World Bank 
Table 3: Swedish Export Statistics by Destination Country

\begin{tabular}{|c|c|c|c|c|c|c|c|}
\hline & \multirow{2}{*}{$\begin{array}{c}\text { Number of } \\
\text { industry- } \\
\text { year obs. }\end{array}$} & \multicolumn{3}{|c|}{$\begin{array}{c}\text { Number of exporters } \\
\text { per industry }\end{array}$} & \multicolumn{3}{|c|}{$\begin{array}{c}\text { Value of exports } \\
\text { per industry, MSEK }\end{array}$} \\
\hline & & Mean & Min & $\operatorname{Max}$ & Mean & Min & Max \\
\hline Congo, Dem. Rep. & 18 & 1.3 & 1 & 3 & 20.9 & 0.0 & 258 \\
\hline Lebanon & 475 & 2.4 & 1 & 19 & 4.0 & 0.0 & 171 \\
\hline Slovenia & 1062 & 3.8 & 1 & 23 & 8.7 & 0.0 & 942 \\
\hline Uganda & 190 & 1.5 & 1 & 7 & 5.0 & 0.0 & 348 \\
\hline Senegal & 115 & 1.7 & 1 & 10 & 2.5 & 0.0 & 42 \\
\hline Guinea-Bissau & 9 & 1.0 & 1 & 1 & 4.9 & 0.0 & 25 \\
\hline Venezuela & 503 & 2.6 & 1 & 19 & 11.9 & 0.0 & 653 \\
\hline United Arab Emirates & 360 & 4.2 & 1 & 30 & 24.3 & 0.0 & 561 \\
\hline Cyprus & 1007 & 2.8 & 1 & 31 & 4.0 & 0.0 & 346 \\
\hline Kuwait & 225 & 2.8 & 1 & 19 & 8.0 & 0.0 & 235 \\
\hline Peru & 466 & 2.6 & 1 & 16 & 6.3 & 0.0 & 248 \\
\hline Tunisia & 372 & 2.4 & 1 & 16 & 9.9 & 0.0 & 442 \\
\hline Slovakia & 965 & 3.7 & 1 & 22 & 9.7 & 0.0 & 364 \\
\hline Macedonia & 148 & 1.9 & 1 & 7 & 2.8 & 0.0 & 70 \\
\hline Ivory Coast & 139 & 1.8 & 1 & 13 & 16.0 & 0.0 & 94 \\
\hline
\end{tabular}

is aggregated in the same way a the Swedish data, by firm size quartiles and destination for each 4-digit NACE rev.1.1 sector. We thus conclude the description of the data with a look at the firm size distribution among those industries in Sweden and Norway that are included in the regressions. Table 4 describes the mean, minimum and maximum number of employees within each size quartile for each 4-digit NACE industry for the year 2005 in Sweden and Norway. The data display a large variation in the mean number of employees across quartiles. Table 4 also shows the subtantial variation in the number of employees across industries for both Sweden and Norway. This highlights the importance of measuring firm size in relative terms using withinindustry quartiles instead of using a raw employee measure in the regression analysis. The firm size statistics in Table 4 indicate that the firm size distribution is similar between Sweden and Norway, which suggests that the regression results by size quartile will be comparable between these two countries. Moreover, the average number of employees per industry and quartile between Sweden and Norway is highly correlated, with a pairwise correlation coefficient of 0.36 that is statistically significant at the $1 \%$ level.

\section{Empirical Specification and Results}

We test for the effect of Swedish embassies on Swedish exports in two main specifications in our analysis. First we test the effect of embassies on the number of exporters each year at the 
Table 4: Firm Size Statistics, 2005

\begin{tabular}{|c|c|c|c|c|}
\hline & \multirow[t]{2}{*}{$\begin{array}{c}\text { Number of } \\
\text { Observations }\end{array}$} & \multicolumn{3}{|c|}{$\begin{array}{l}\text { Avg. number of employees } \\
\text { per industry and quartile }\end{array}$} \\
\hline & & Mean & Min & Max \\
\hline \multicolumn{5}{|l|}{ Sweden } \\
\hline 1st quartile & 24 & 13.9 & 10.8 & 30.0 \\
\hline 2nd quartile & 52 & 39.6 & 14.5 & 130.0 \\
\hline 3rd quartile & 113 & 88.9 & 23.2 & 387.4 \\
\hline 4th quartile & 497 & 634.2 & 47.9 & 5992.5 \\
\hline \multicolumn{5}{|l|}{ Norway } \\
\hline 1st quartile & 9 & 12.0 & 10.0 & 14.0 \\
\hline 2nd quartile & 46 & 38.2 & 13.0 & 175.0 \\
\hline 3rd quartile & 102 & 62.4 & 19.0 & 461.0 \\
\hline 4th quartile & 426 & 236.7 & 20.0 & 1521.3 \\
\hline
\end{tabular}

Note: Based on observations included in regression in Table 6, column (2). Source: Statistics Sweden, authors' calculations

industry-destination-level. ${ }^{7}$ We then disaggregate the industry-level data by firm size quartiles and test whether the effect of embassies differs across quartiles of the firm size distribution. We use as control export by Norwegian firms by sector and quartile. We use weighted least squares in all specifications, weighting by industry output. Weighting for industry size is motivated in this context by the heterogeneity in industry size across Swedish manufacturing firms.

\subsection{Industry-Level Results}

Our industry-destination-level regressions use the following specification:

$$
\log \left(N_{i c t+1}\right)=\beta_{0}+\beta_{1} E m b \_d u m_{c t}+\text { controls }_{c t}+d_{i t}+d_{i c}+\varepsilon_{i c t}
$$

where $N_{i c t+1}$ is the number of exporters from 4-digit NACE rev.1.1 industry $i$ to destination country $c$ in year $t+1$. Emb_dum $m_{c t}$ is the embassy dummy. $d_{i t}$ and $d_{i c}$ are industry*year and industry*country fixed effects and $\varepsilon_{i c t}$ is the error term. Our theoretical model implies that $\beta_{1}$ should have a positive sign.

We begin by measuring the effect of embassies on the number of exporters by destination and sector. The results regressing equation (15) are presented in Table 5. The results in column (1) include country*industry fixed effects, meaning that the results can be interpreted as the effect of embassy presence on the firm extensive margin over time. The year dummies controls

\footnotetext{
${ }^{7} \mathrm{An}$ alternative is to test for the effects of export promotion on exporter productivity. However, productivity is more subject to swings in the business cycle and therefore much more volatile than employment. There are also several issues concerning the measurement of productivity. We nonetheless report the results using productivity quartiles in the robustness section.
} 
Table 5: Effect of embassies on the number of exporters

(2)

\begin{tabular}{|c|c|c|}
\hline emb_dum ${ }_{\mathrm{ct}}$ & $\begin{array}{c}0.035 \\
(0.023)\end{array}$ & $\begin{array}{c}0.048 \\
(0.023)^{\star *}\end{array}$ \\
\hline In_pop ${ }_{\mathrm{ct}}$ & $\begin{array}{c}-0.928 \\
(0.350)^{\star * *}\end{array}$ & $\begin{array}{c}-1.116 \\
(0.373)^{\star * \star}\end{array}$ \\
\hline In_cgdp $p_{c t}$ & $\begin{array}{c}0.154 \\
(0.078)^{\star *}\end{array}$ & $\begin{array}{c}0.150 \\
(0.087)^{*}\end{array}$ \\
\hline $\operatorname{tariff}_{\mathrm{ct}}$ & $\begin{array}{c}0.000 \\
(0.003)\end{array}$ & $\begin{array}{c}0.000 \\
(0.003)\end{array}$ \\
\hline $\mathrm{oda}_{\mathrm{ct}}$ & $\begin{array}{c}0.002 \\
(0.001)\end{array}$ & $\begin{array}{c}0.002 \\
(0.002)\end{array}$ \\
\hline EUdum $_{\mathrm{ct}}$ & $\begin{array}{c}0.033 \\
(0.034)\end{array}$ & $\begin{array}{l}-0.019 \\
(0.036)\end{array}$ \\
\hline $\begin{array}{l}\text { Country*industry fixed effects } \\
\text { Year fixed effects } \\
\text { industry*year fixed effects }\end{array}$ & $\begin{array}{l}\text { YES } \\
\text { YES } \\
\text { NO }\end{array}$ & $\begin{array}{l}\text { YES } \\
\text { NO } \\
\text { YES }\end{array}$ \\
\hline $\begin{array}{l}\text { Observations } \\
\mathrm{R}^{2}\end{array}$ & $\begin{array}{l}5485 \\
0.017\end{array}$ & $\begin{array}{l}5485 \\
0.371\end{array}$ \\
\hline $\begin{array}{l}\text { Notes: This table presents est } \\
\text { log(number of exporters) from } \\
\text { in year } t+1 \text {. Weighted Least } S \\
\text { annual industry-level sales. R } \\
\text { *** } p<0.01,{ }^{* \star} p<0.05,{ }^{*} p<0.1\end{array}$ & $\begin{array}{l}\text { Dependen } \\
1.1 \text { industr } \\
\text { reported, w } \\
\text { ors in parer }\end{array}$ & $\begin{array}{l}\text { ariable: } \\
\text { o country c } \\
\text { ted by } \\
\text { ses. }\end{array}$ \\
\hline
\end{tabular}

for any type of trend in export patterns over time. Column (2) includes country*industry fixed effects plus industry*year fixed effects in order to control for differences in export growth across industries that may drive our results. In column (2) Emb_dumct has a positive coefficient and is significant at the $5 \%$ level. The coefficient on $E m b \_d u m_{c t}$ indicates that the presence of a Swedish embassy is associated with a $5 \%$ increase in the number of Swedish exporters within a 4-digit NACE rev. 1.1 industry. 


\subsection{Industry-Quartile-Level Results}

Our more dissaggregated industry-quartile-destination-level regressions use the following specification:

$$
\log \left(N_{\text {qict }+1}\right)=\beta_{0}+\sum_{r=1}^{4} \beta_{r}\left(E m b \_d u m_{c t} \times Q^{r}\right)+\text { controls }_{c t}+d_{i t}+d_{q i c}+\varepsilon_{q i c t},
$$

where $N_{\text {qict+1 }}$ is the number of exporters in quartile $q$ from 4-digit NACE rev.1.1 industry $i$ to destination country $c$ in year $t+1$. Emb_dum $m_{c t}$ is now interacted with four size quartile indicator variables $Q^{r}$, which take the value of 1 when an observation belongs to quartile $r$. $d_{i t}$ and $d_{q i c}$ are industry*year and industry* quartile*country fixed effects and $\varepsilon_{\text {qict }}$ is the error term. Theory implies that at least some of the $\beta^{\prime} s$ should have a positive sign.

The effect of embassy presence on the number of exporters across different quartiles of the firm size distribution, as described in equation (16), is presented in Table 6. The coefficients of interest are the four interactions of $E m b \_d u m_{c t}$ with the firm size quartile indicator variables. Column (1) of Table 6 uses country*industry*quartile fixed effects plus year fixed effects, meaning that the coefficients can be interpreted as the percentage increase in the number of firms over time for any country*industry*quartile. The year dummies controls for any general trends in export behavior over time. Industry*year fixed effects are added in column (2), which controls for any industry-specific trends in the extensive margin that may drive our results. Finally, we add size quartile*year fixed effects in column (3) in order to remove quartile-specific trends that may be driving our results. Our finding that medium-sized and large firms respond most strongly to embassy presence is robust across all specifications. In column (3) embassy presence leads to an $9 \%$ and $5 \%$ increase in the number of exporters in the third and fourth quartiles of the firm size distribution respectively. The result for the third quartile is robust and highly significant across specifications. We find no statistical significant point estimates for the first or second quartiles of the firm size distribution. Overall, these initial results are promising and fit our theoretical prediction that medium-sized firms will respond most strongly to lower fixed costs to export via the foreign service.

The results in Table 6 provide a much richer picture of the heterogeneous impact of embassies on the firm extensive margin and emphasize that firm size is an important factor when measuring the impact of the foreign service. Given that the export destinations we study are smaller and more distant we find it reassuring that it is the third quartile that responds most to embassy presence, as these destinations are arguably more "exotic" and would not be served by small firms.

\subsection{Pretreatment and Posttreatment Effects}

Our theoretical approach assumes that embassies make it easier for some firms to export. However, one may argue that embassies may be built in places where medium-sized firms have already begun exporting. In order to establish that our results are consistent with the hypothesis that export promotion via the foreign service reduce entry barriers we examine the 
Table 6: Effect of embassies on the number of exporters, by size quartile

(1)

\begin{tabular}{|c|c|c|c|}
\hline emb_dum ${ }_{\mathrm{ct}} \times 1$ st quartile & $\begin{array}{c}0.025 \\
(0.103)\end{array}$ & $\begin{array}{c}0.201 \\
(0.169)\end{array}$ & $\begin{array}{c}0.303 \\
-0.208\end{array}$ \\
\hline emb_dum ${ }_{\mathrm{ct}} \times 2$ nd quartile & $\begin{array}{l}-0.005 \\
(0.065)\end{array}$ & $\begin{array}{l}-0.005 \\
(0.081)\end{array}$ & $\begin{array}{l}0.025 \\
-0.085\end{array}$ \\
\hline emb_dum ${ }_{\mathrm{ct}} \times 3$ rd quartile & $\begin{array}{c}0.118 \\
(0.041)^{\star \star *}\end{array}$ & $\begin{array}{c}0.115 \\
(0.043)^{\star \star \star}\end{array}$ & $\begin{array}{c}0.094 \\
(0.045)^{\star *}\end{array}$ \\
\hline emb_dum ${ }_{\mathrm{ct}} \times 4$ th quartile & $\begin{array}{c}0.032 \\
(0.019)\end{array}$ & $\begin{array}{c}0.049 \\
(0.020)^{\star *}\end{array}$ & $\begin{array}{c}0.052 \\
(0.020)^{\star * *}\end{array}$ \\
\hline In_pop ${ }_{\mathrm{ct}}$ & $\begin{array}{c}-0.959 \\
(0.395)^{\star *}\end{array}$ & $\begin{array}{c}-0.793 \\
(0.419)^{*}\end{array}$ & $\begin{array}{c}-0.735 \\
(0.420)^{*}\end{array}$ \\
\hline In_cgdp ${ }_{c t}$ & $\begin{array}{c}0.291 \\
(0.090)^{\star \star *}\end{array}$ & $\begin{array}{c}0.266 \\
(0.099)^{\star \star *}\end{array}$ & $\begin{array}{c}0.231 \\
(0.099)^{\star *}\end{array}$ \\
\hline tariff $_{\mathrm{ct}}$ & $\begin{array}{l}-0.001 \\
(0.003)\end{array}$ & $\begin{array}{l}-0.001 \\
(0.003)\end{array}$ & $\begin{array}{l}-0.002 \\
-0.003\end{array}$ \\
\hline oda $\mathrm{ct}_{\mathrm{ct}}$ & $\begin{array}{c}0.001 \\
(0.001)\end{array}$ & $\begin{array}{c}0.000 \\
(0.002)\end{array}$ & $\begin{array}{c}0.000 \\
-0.002\end{array}$ \\
\hline EUdum $_{\mathrm{ct}}$ & $\begin{array}{l}-0.018 \\
(0.037)\end{array}$ & $\begin{array}{l}-0.062 \\
(0.039)\end{array}$ & $\begin{array}{l}-0.062 \\
-0.039\end{array}$ \\
\hline $\begin{array}{l}\text { Country }{ }^{*} \text { industry }{ }^{*} \text { quartile fixed effects } \\
\text { Year fixed effects } \\
\text { Industry*year fixed effects } \\
\text { Quartile*year fixed effects }\end{array}$ & $\begin{array}{l}\text { YES } \\
\text { YES } \\
\text { NO } \\
\text { NO }\end{array}$ & $\begin{array}{l}\text { YES } \\
\text { NO } \\
\text { YES } \\
\text { NO }\end{array}$ & $\begin{array}{l}\text { YES } \\
\text { NO } \\
\text { YES } \\
\text { YES }\end{array}$ \\
\hline $\begin{array}{l}\text { Observations } \\
\mathrm{R}^{<}\end{array}$ & $\begin{array}{l}4724 \\
0.020\end{array}$ & $\begin{array}{l}4724 \\
0.337\end{array}$ & $\begin{array}{l}4724 \\
0.349\end{array}$ \\
\hline
\end{tabular}

Notes: This table presents the estimates of Eq. (16). Dependent variable:

log(number of exporters) from employment quartile q of 4-digit NACE rev. 1.1 industry $i$ to country $c$ in year $t+1$. Weighted Least Squares estimates reported, weighted by annual industry-level sales. Robust standard errors in parentheses. ${ }^{* * *} p<0.01,{ }^{* *} p<0.05,{ }^{*} p<0.1$ 
extensive margin of exporting before, during, and after the embassies were built. If embassies cause exporting then we should find no change in the number of exporters prior to the opening or closing of embassies. We focus here on the industry-quartile-level data.

We use the following specification to measure pretreatment and posttreatment effects in the quartile-industry-level data, based on equation (16):

$$
\log \left(N_{\text {qict }}\right)=\beta_{0}+\sum_{s=-2}^{2} \sum_{r=1}^{4} \beta_{r, t+s}\left(\text { Emb_open }_{c, t+s} \times Q^{r}\right)+\text { controls }_{c t}+d_{i t}+d_{q i c}+\varepsilon_{q i c t} .
$$

$N_{\text {qict }}$ is the number of exporters in quartile $q$ from 4-digit NACE rev.1.1 industry $i$ to destination country $c$ in year $t$. Emb_open E,$t+s_{\text {in }}$ is a dummy variable taking a value of one if a Swedish embassy was built in year $t+s$ in country $c$, minus one if a Swedish embassy was closed in year $t+s$ in country $c$, and zero otherwise. ${ }^{8}$ For example, Emb_open ${ }_{c, t+2}$ is equal to one for the year 2000 if the embassy in country $c$ was built in 2002 and zero in all other years. This set of indicators allows for two posttreatment yearly effects $\left(\beta_{r, t-1}, \beta_{r, t-2}\right)$, a contemporaneous effect $\left(\beta_{r, t}\right)$ and two pretreatment yearly effects $\left(\beta_{r, t+1}, \beta_{r, t+2}\right)$. The various pretreatment and posttreatment effects are interacted with four size quartile indicator variables $Q^{r}$, which take the value of 1 when an observation belongs to quartile $r$. We employ industry*country*quartile, industry*year and quartile*year fixed effects.

The results of the pretreatment and posttreatment estimation for the third quartile of the firm size distribution is graphically depicted in figure 1. We focus on the third quartile here because the baseline regression results in Table 6 suggest that it was the quartile that responded most vigorously to the embassy openings and closures. The pre-treatment trend is stable in Figure 1, with a statistically significant change in the number of exporters in the third size quartile one year after the embassy is opened or closed, with almost no effect before the year the embassy changes status. However, this effect is not visible two years after the embasssy is opened or closed.

\subsection{Using Norway as Control}

Our analysis so far has not considered the fact that trade patterns and diplomatic relations may both be determined by some third factor such as a political or economic event in the destination country. Spurious correlation between diplomatic and economic openness of countries in our sample may be a serious concern. Moreover, we may have a problem of omitted variables at the country-year or country-industry-quartile-year level in our earlier regression analysis.

We address this issue by using Norwegian firms as a control group since they should not be affected by the opening or closing of Swedish embassies. This identification strategy assumes that percentage changes in the extensive margin of Norwegian firms ought to mimic Swedish firms except in the case when Sweden opens or closes an embassy.

\footnotetext{
${ }^{8}$ Only considering embassy openings produces a very similar figure.
} 


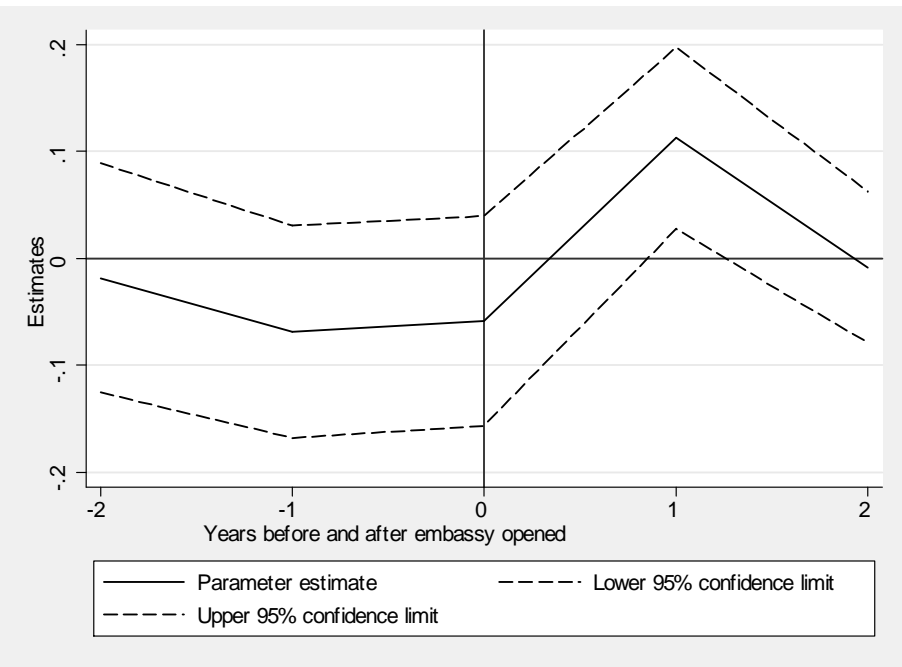

Figure 1: Third quartile estimates and the $95 \%$ confidence interval from two years before to two years after opening an embassy. Notes: This graph presents the estimates of Eq.(17)

There are many reasons that Norwegian firms serve as a highly appropriate control group. First, Norway and Sweden share a border and have thus similar trade costs to reach the various countries where embassies were opened or closed. Second, Sweden and Norway are very similar countries in terms of income and institutional development. Third, Norway did not always open embassies at the same time as Sweden for the countries we study. Norway opened embassies in Slovenia in 2003 and Slovakia in 2004, which we control for in our analysis.

\subsubsection{Norway Placebo Treatment}

We first run a placebo specification by regressing the Swedish embassy data on the number of Norwegian exporters within each size quartile. We predict that there should be no effect of opeing Swedish embassies on Norwegian exporters. The results are presented in Table 7, using the same fixed effects and controls as Table 6 . We find no statistically significant estimates across all quartiles. ${ }^{9}$ These findings help to reassure that our main results are not driven spuriously by a general increase in economic and diplomatic openness that would affect other countries' exports.

\subsubsection{Sweden-Norway Difference-in-Differences}

We also employ a difference-in-differences empirical strategy using the Norwegian exporter data and Norwegian embassy status as a control. For each industry-quartile-destination for which we have both Swedish and Norwegian data on the number of exporters each year we calculate the

\footnotetext{
${ }^{9}$ Note that the interaction of $E m b \_d u m_{c t}$ with the first Norwegian size quartile dummy is not reported in column (1) of Table 7. This occurs because there there were no firms in the first size quartile that exported to countries where an embassy was built. The interaction term is thus perfectly correlated with the quartile*year fixed effects and is subsequently dropped from the regression.
} 
Table 7: Norwegian Placebo Treatment

(1)

(2)

(3)

\begin{tabular}{|c|c|c|c|}
\hline emb_dum ${ }_{\mathrm{ct}} \times 2$ 2nd quartile & $\begin{array}{l}-0.021 \\
(0.090)\end{array}$ & $\begin{array}{l}-0.217 \\
(0.157)\end{array}$ & $\begin{array}{l}-0.046 \\
(0.153)\end{array}$ \\
\hline emb_dum $_{\mathrm{ct}} \times 3$ rd quartile & $\begin{array}{l}-0.034 \\
(0.077)\end{array}$ & $\begin{array}{l}-0.126 \\
(0.101)\end{array}$ & $\begin{array}{l}-0.104 \\
(0.091)\end{array}$ \\
\hline emb_dum ${ }_{\mathrm{ct}} \times 4$ th quartile & $\begin{array}{l}-0.027 \\
(0.036)\end{array}$ & $\begin{array}{l}-0.061 \\
(0.04)\end{array}$ & $\begin{array}{l}-0.064 \\
(0.040)\end{array}$ \\
\hline In_pop ${ }_{\mathrm{ct}}$ & $\begin{array}{c}0.869 \\
(0.974)\end{array}$ & $\begin{array}{c}1.193 \\
(1.179)\end{array}$ & $\begin{array}{c}0.845 \\
(1.168)\end{array}$ \\
\hline In_cgdp ${ }_{c t}$ & $\begin{array}{l}-0.020 \\
(0.193)\end{array}$ & $\begin{array}{c}0.023 \\
(0.238)\end{array}$ & $\begin{array}{l}-0.014 \\
(0.238)\end{array}$ \\
\hline $\operatorname{tariff}_{\mathrm{ct}}$ & $\begin{array}{l}0.005 \\
(0.005)\end{array}$ & $\begin{array}{c}0.002 \\
(0.006)\end{array}$ & $\begin{array}{c}0.003 \\
(0.006)\end{array}$ \\
\hline oda $_{\text {ct }}$ & $\begin{array}{c}0.031 \\
(0.015)^{\star \star}\end{array}$ & $\begin{array}{c}0.026 \\
(0.018)\end{array}$ & $\begin{array}{c}0.023 \\
(0.019)\end{array}$ \\
\hline EUdum $_{\mathrm{ct}}$ & $\begin{array}{c}0.103 \\
(0.075)\end{array}$ & $\begin{array}{c}0.184 \\
(0.093)^{\star *}\end{array}$ & $\begin{array}{c}0.166 \\
(0.093)^{*}\end{array}$ \\
\hline $\begin{array}{l}\text { Country*industry* quartile fixed effects } \\
\text { Year fixed effects } \\
\text { Industry*year fixed effects } \\
\text { Quartile*year fixed effects }\end{array}$ & $\begin{array}{l}\text { YES } \\
\text { YES } \\
\text { NO } \\
\text { NO }\end{array}$ & $\begin{array}{l}\text { YES } \\
\text { NO } \\
\text { YES } \\
\text { NO }\end{array}$ & $\begin{array}{l}\text { YES } \\
\text { NO } \\
\text { YES } \\
\text { YES }\end{array}$ \\
\hline $\begin{array}{l}\text { Observations } \\
\mathrm{R}^{<}\end{array}$ & $\begin{array}{l}1165 \\
0.021\end{array}$ & $\begin{array}{l}1165 \\
0.462\end{array}$ & $\begin{array}{l}1165 \\
0.483\end{array}$ \\
\hline
\end{tabular}

Notes: This table presents estimates based on Eq. (16). Dependent variable:

Norwegian log(number of exporters) from employment quartile q of 4-digit NACE rev. 1.1 industry $i$ to country $c$ in year $t+1$. Weighted Least Squares estimates reported, weighted by Swedish annual industry-level sales. Robust standard errors in parentheses. ${ }^{* * *} p<0.01,{ }^{* *} p<0.05,{ }^{*} p<0.1$ 
difference between the log number of Swedish firms and the log number of Norwegian firms. This identification strategy arguably controls for unobservable factors that may affect the extensive margin for any industry-quartile-country combination. Our first-differenced specification takes the following form:

$$
\Delta \log \left(N_{\text {qict }+1}\right)=\beta_{0}+\sum_{r=1}^{4} \beta_{r}\left(\Delta E m b_{-} d u m_{c t} \times Q^{r}\right)+\text { controls }_{c t}+d_{i}+d_{t}+\varepsilon_{q i c t},
$$

where $\Delta \log \left(N_{\text {qict }+1}\right)=\log \left(N_{\text {qict }+1 \_S w e}\right)-\log \left(N_{\text {qict }+1 \_N o r}\right)$ is the percentage difference in the number of exporters in quartile $q$ from 4-digit NACE rev.1.1 industry $i$ to destination country $c$ in year $t+1$ from Sweden and Norway respectively. We first-difference the embassy

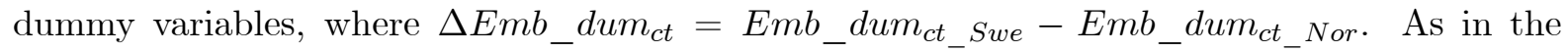
previous specification, the embassy dummy term is interacted with four size quartile indicator

variables. $\varepsilon_{\text {qict }}$ is the error term. $d_{i}$ and $d_{t}$ are industry and year fixed effects respectively. Our theory implies that at least some of the $\beta^{\prime} s$ should have a positive sign.

Our results using the Norwegian data and regressing equation (18) are presented in Table 8. First-differencing the data controls for all omitted country-industry-quartile-year variables. We include industry fixed effects in column (1) of Table 8 in order to control for systematic differences in industry-level export patterns between Sweden and Norway. In column (2) of Table 8 we add year fixed effects to control for differential time trends. We also include a control for EU membership since Sweden is an EU member while Norway is not. One drawback to this approach is that we do not always have a match between the Swedish and Norwegian data, which leads to a smaller number of observations in the first-differenced sample. Nonetheless, even using this demanding specification we find a statistically significant effect of embassies on the fourth quartile of the firm size distribution at the $5 \%$ level. This result provides further reassurance that our results are not spurious. We also find that the coefficient on the EU membership dummy is positive and significant.

\subsection{Further Robustness}

We have compared the response of firms to embassies along the dimension of firm size as measured by the number of employees. Our rationale is that employment is more consistent over time compared to productivity measures. Nonetheless, it is worthwhile as a robustness check to investigate whether our results hold when comparing the response of firms divided into firm productivity quartiles. To this end, we calculate firm-level productivity using the Levinsohn-Petrin (2003) approach, then sort firms into firm productivity quartiles by year and industry. The results of using productivity quartiles are presented in column (1) of Table 9. We obtain a statistically significant point estimate for the fourth productivity quartile in this case. This result is consistent with our thesis that larger firms respond most vigorously to the opening or closing of embassies.

While our theory is relevant for explaining how firms react when embassies are either opened or closed, it can be argued that the opening of an embassy is a cleaner experiment since firms 
Table 8: Sweden Norway Difference-in-Differences

(1)

(2)

\begin{tabular}{|c|c|c|}
\hline emb_dum ${ }_{\mathrm{ct}} \times 1$ st quartile & $\begin{array}{l}-0.078 \\
(0.13)\end{array}$ & $\begin{array}{l}-0.077 \\
(0.135)\end{array}$ \\
\hline$\Delta$ emb_dum ${ }_{\text {ct }} \times 2$ 2nd quartile & $\begin{array}{l}-0.097 \\
(0.071)\end{array}$ & $\begin{array}{l}-0.107 \\
(0.071)\end{array}$ \\
\hline$\Delta$ emb_dum ${ }_{\text {ct }} \times 3 r d$ quartile & $\begin{array}{l}-0.021 \\
(0.037)\end{array}$ & $\begin{array}{l}-0.035 \\
(0.037)\end{array}$ \\
\hline$\Delta \mathrm{emb}_{\mathrm{d}} \mathrm{dum}_{\mathrm{ct}} \times$ 4th quartile & $\begin{array}{c}0.046 \\
(0.016)^{\star \star \star}\end{array}$ & $\begin{array}{c}0.034 \\
(0.016)^{\star *}\end{array}$ \\
\hline EUdum $_{\mathrm{ct}}$ & $\begin{array}{c}0.137 \\
(0.031)^{\star \star *}\end{array}$ & $\begin{array}{c}0.259 \\
(0.038)^{\star \star *}\end{array}$ \\
\hline $\begin{array}{l}\text { Industry fixed effects } \\
\text { Year fixed effects }\end{array}$ & $\begin{array}{l}\text { YES } \\
\text { NO }\end{array}$ & $\begin{array}{l}\text { YES } \\
\text { YES }\end{array}$ \\
\hline $\begin{array}{l}\text { Observations } \\
R^{<}\end{array}$ & $\begin{array}{l}4471 \\
0.294\end{array}$ & $\begin{array}{l}4471 \\
0.300\end{array}$ \\
\hline \multicolumn{3}{|c|}{$\begin{array}{l}\text { Notes: This table presents the estimates of equation (18). Dependent variable: differenc } \\
\text { in log(number of exporters) from employment quartile } q \text { of } 4 \text {-digit NACE Rev. } 1.1 \\
\text { industry i to country c in year } t+1 \text { between Sweden and Norway. Weighted Least } \\
\text { Squares estimates reported, weighted by Swedish annual industry-level sales. Robust } \\
\text { standard errors in parentheses. }{ }^{* \star}{ }^{* *} p<0.01,{ }^{* *} p<0.05,{ }^{*} p<0.1\end{array}$} \\
\hline
\end{tabular}


that already export are less likely to leave the market due to an embassy closure. As a further robustness check we restrict the analysis to include only destinations where Swedish embassies were opened. The embassy dummy takes a value equal to one if an embassy open and zero if there is no embassy. This approach leaves us with eight destination countries to our analysis (Dem. Rep. Congo, Slovenia, Uganda, Senegal, United Arab Emirates, Cyprus, Slovakia, and Macedonia). The results of restricting to embassy openings in our analyis is given in column (2) of Table 9. Reassuringly, we obtain a statistically significant point estimate for the third quartile of the firm size distribution.

Another potential concern is that our results are driven by industries where there are few firms. We address this concern by restricting the regression analysis to industries that have at least 20 firms operating each year. The results using this restricted sample are provided in column (3) of Table 9. Compared to our baseline results, we find that a more restrictive lower bound on firm size leads to a statistically significant response from the fourth productivity quartile. Overall, our results are robust to a wide variety of alternative specifications, with the third and/or fourth quartiles of the firms size distribution responding to embassy openings across our analysis.

\section{Conclusion}

The purpose of this study was to investigate the effects of export promotion by Swedish embassies. We view the export promotion of embassies as decreasing the barrier to entry foreign markets. The importance of a fixed foreign market entry cost will depend on the firm size, and we therefore focus on firm size in determining how the extensive margin of exports responds to opening and closing embassies. In doing we directly test the prediction of the Melitz model with unilateral trade liberalization that trade liberalization allows less productive firms to begin exporting. We develop a Melitz-based model where firms are heterogeneous with respect to productivity and must pay a fixed cost to entry the entry market, which can be reduced by goverment spending on trade promotion. The model predicts that unilateral trade promotion allows new medium-sized and large firms to export. We test this prediction using Swedish firmlevel data and information on the opening and closing of Swedish embassies abroad. Our results hold in several robustness checks, including when we use Norwegian firms as a control group. Moreover, the results suggest that the number of exporters increases after the embassy is built, which is consistent with the prediction of our theoretical framework. Our results suggest that embassies play an important role in promoting the exports of medium-sized and large firms. 
Table 9: Results by productivity quartile and selected subsamples

\begin{tabular}{|c|c|c|c|}
\hline & \multirow{2}{*}{$\begin{array}{c}\begin{array}{c}\text { Productivity } \\
\text { quartiles }\end{array} \\
\text { Full } \\
\text { sample } \\
\text { (1) }\end{array}$} & \multicolumn{2}{|c|}{ Size quartiles } \\
\hline & & $\begin{array}{l}\text { Embassy } \\
\text { openings } \\
\text { only } \\
\text { (2) }\end{array}$ & $\begin{array}{l}\text { Minimum } \\
20 \text { firms } \\
\text { per industry } \\
\text { (3) }\end{array}$ \\
\hline emb_dum ${ }_{\mathrm{ct}} \times 1$ st quartile & $\begin{array}{l}-0.125 \\
(0.274)\end{array}$ & $\begin{array}{c}0.230 \\
(0.238)\end{array}$ & $\begin{array}{c}0.172 \\
(0.344)\end{array}$ \\
\hline emb_dum $\mathrm{ct}_{\mathrm{ct}} \times 2$ nd quartile & $\begin{array}{c}0.080 \\
(0.107)\end{array}$ & $\begin{array}{l}-0.058 \\
(0.151)\end{array}$ & $\begin{array}{c}0.112 \\
(0.112)\end{array}$ \\
\hline emb_dum ${ }_{\mathrm{ct}} \times 3$ rd quartile & $\begin{array}{c}0.059 \\
(0.051)\end{array}$ & $\begin{array}{c}0.143 \\
(0.078)^{*}\end{array}$ & $\begin{array}{c}0.086 \\
(0.056)\end{array}$ \\
\hline emb_dum ${ }_{\text {ct }} \times 4$ th quartile & $\begin{array}{c}0.040 \\
(0.022)^{*}\end{array}$ & $\begin{array}{l}-0.017 \\
(0.033)\end{array}$ & $\begin{array}{c}0.049 \\
(0.025)^{\star}\end{array}$ \\
\hline In_pop ${ }_{\mathrm{ct}}$ & $\begin{array}{c}-1.345 \\
(0.463)^{\star \star \star}\end{array}$ & $\begin{array}{l}-0.618 \\
(0.597)\end{array}$ & $\begin{array}{c}-1.375 \\
(0.520)^{\star \star \star}\end{array}$ \\
\hline In_cgdp $p_{c t}$ & $\begin{array}{c}0.071 \\
(0.102)\end{array}$ & $\begin{array}{c}0.249 \\
(0.229)\end{array}$ & $\begin{array}{c}0.123 \\
(0.112)\end{array}$ \\
\hline $\operatorname{tariff}_{\mathrm{ct}}$ & $\begin{array}{c}0.000 \\
(0.004)\end{array}$ & $\begin{array}{c}0.017 \\
(0.009)^{\star \star}\end{array}$ & $\begin{array}{c}0.001 \\
(0.004)\end{array}$ \\
\hline $\mathrm{oda}_{\mathrm{ct}}$ & $\begin{array}{c}0.000 \\
(0.002)\end{array}$ & $\begin{array}{l}-0.002 \\
(0.002)\end{array}$ & $\begin{array}{l}-0.001 \\
(0.002)\end{array}$ \\
\hline EUdum $_{\mathrm{ct}}$ & $\begin{array}{c}-0.098 \\
(0.044)^{\star *}\end{array}$ & $\begin{array}{c}-0.120 \\
(0.061)^{\star *}\end{array}$ & $\begin{array}{c}-0.121 \\
(0.051)^{\star *}\end{array}$ \\
\hline $\begin{array}{l}\text { Country*industry* }{ }^{*} \text { quartile fixed effects } \\
\text { Industry*year fixed effects } \\
\text { Quartile*year fixed effects }\end{array}$ & $\begin{array}{l}\text { YES } \\
\text { YES } \\
\text { YES }\end{array}$ & $\begin{array}{l}\text { YES } \\
\text { YES } \\
\text { YES }\end{array}$ & $\begin{array}{l}\text { YES } \\
\text { YES } \\
\text { YES }\end{array}$ \\
\hline $\begin{array}{l}\text { Observations } \\
\mathrm{R}^{<}\end{array}$ & $\begin{array}{l}4726 \\
0.312\end{array}$ & $\begin{array}{l}3211 \\
0.442\end{array}$ & $\begin{array}{l}3562 \\
0.289\end{array}$ \\
\hline
\end{tabular}

Notes: This table presents the estimates based on Eq. (16). Dependent variable in column (1): $\log$ (number of exporters) from productivity quartile q of 4-digit NACE rev. 1.1 industry $i$ to country $c$ in year $t+1$. Dependent variable in columns (2)-(3): $\log$ (number of exporters) from employment quartile q of 4-digit NACE rev. 1.1 industry $i$ to country $c$ in year $t+1$. Weighted Least Squares estimates reported, weighted by annual industry-level sales. Robust standard errors in parentheses. ${ }^{* * *} p<0.01,{ }^{* *} p<0.05,{ }^{*} p<0.1$ 


\section{A Mathematical Appendix}

\section{A.1 Proof of Proposition 1:}

The effect of home country trade promotion on home's domestic firms's marginal cost cutoff can be seen in the following derivative:

$$
\frac{\partial a_{D j}^{\theta}}{\partial d_{j k}}=\frac{F_{E} \eta(\beta-1)^{2} \Omega d_{j k}^{\beta-2}\left(-1+d_{k j}^{\beta-1} \Omega\right)}{F_{X}\left(-1+d_{j k}^{\beta-1} d_{k j}^{\beta-1} \Omega^{2}\right)^{2}}
$$

The derivative is negative for $d_{k j}=1$ and $\Omega \in[0,1) \forall j, k$.

\section{A.2 Proof of Proposition 2:}

The effect of unilateral foreign country trade promotion on home's marginal cost cutoff can be seen in the following derivative:

$$
\frac{\partial a_{X j}^{\theta}}{\partial d_{k j}}=\frac{F_{E} \eta(\beta-1)^{2} \Omega^{2} d_{k j}^{\beta-2} d_{j k}^{\beta}\left(-1+d_{j k}^{\beta-1} \Omega\right)}{F_{X}\left(-1+d_{j k}^{\beta-1} d_{k j}^{\beta-1} \Omega^{2}\right)^{2}}
$$

The derivative is negative for $d_{j k}=1$ and $\Omega<1$. 


\section{References}

Akerman, A., and R. Forslid (2007): "Country Size, Productivity and Trade Share Convergence: An Analysis of Heterogenous Firms and Country Size Dependent Beachhead Costs," CEPR Discussion Papers 6545, C.E.P.R. Discussion Papers.

Breinlich, H., And A. Cuñat (2010): "Trade Liberalization and Heterogeneous Firm Models: An Evaluation Using the Canada - US Free Trade Agreement," CEPR Discussion Papers 7668, C.E.P.R. Discussion Papers.

Girma, S., Y. Gong, H. Görg, and Z. Yu (2009): "Can Production Subsidies Explain China's Export Performance? Evidence from Firm-level Data," Scandinavian Journal of Economics, 111(4), 863-891.

Görg, H., M. Henry, and E. Strobl (2008): "Grant Support and Exporting Activity," Review of Economics 8 Statistics, 90(1), 168 - 174.

Helpman, E., M. J. Melitz, and S. R. Yeaple (2004): "Export Versus FDI with Heterogeneous Firms," American Economic Review, 94(1), 300-316.

Lederman, D., M. Olarreaga, and L. Payton (2010): "Export promotion agencies: Do they work?," Journal of Development Economics, 91(2), 257-265.

Levinsohn, J., and A. Petrin (2003): "Estimating Production Functions Using Inputs to Control for Unobservables," Review of Economic Studies, 70(2), 317-341.

Melitz, M. J. (2003): "The Impact of Trade on Intra-Industry Reallocations and Aggregate Industry Productivity," Econometrica, 71(6), 1695-1725.

Nitsch, V. (2007): "State Visits and International Trade," The World Economy, 30(12), 17971816.

Persson, M. (2013): "Trade facilitation and the extensive margin," Journal of International Trade and Economic Development, 5, 658-693.

Rose, A. K. (2007): "The Foreign Service and Foreign Trade: Embassies as Export Promotion," The World Economy, 30(1), 22-38.

Trefler, D. (2004): "The Long and Short of the Canada-U. S. Free Trade Agreement," American Economic Review, 94(4), 870-895.

Volpe Martincus, C., and J. Carballo (2008): "Is export promotion effective in developing countries? Firm-level evidence on the intensive and the extensive margins of exports," Journal of International Economics, 76(1), 89 - 106.

(2010): "Beyond the average effects: The distributional impacts of export promotion programs in developing countries," Journal of Development Economics, 92(2), 201 - 214. 
Volpe Martincus, C., J. Carballo, and P. M. Garcia (2012): "Public programmes to promote firms' exports in developing countries: are there heterogeneous effects by size categories?," Applied Economics, 44(4), 471-491. 